\title{
Efek Fermentasi Basah Menggunakan Kultur Saccharomyces cerevisiae Terhadap Sifat Kimia dan Sensori Kopi Robusta (Coffea canephora)
}

\section{Effect of Wet Fermentation Using Saccharomyces cerevisiae on Chemical Properties and Sensory of Robusta Coffee (Coffea canephora)}

\author{
Dyah Putri Larassati ${ }^{1}$, Maria Erna Kustyawati ${ }^{1 凶}$, Subeki $^{1}$, Dewi Sartika ${ }^{1}$, Suharyono AS \\ ${ }^{1}$ Magister Teknologi Industri Pertanian, Fakultas Pertanian, Universitas Lampung

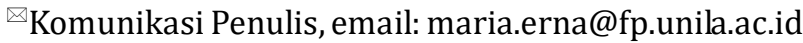 \\ DOI:http://dx.doi.org/10.23960/jtep-lv10i4.449-458
}

Naskah ini diterima pada 5 Maret 2021; revisi pada 28 April 2021;

disetujui untuk dipublikasikan pada 6 Desember 2021

\begin{abstract}
High levels of caffeine in Robusta coffee beans can be reduced by Wet coffee fermentation. Saccharomyces cerevisiae an excellent hydrolytic enzyme producer has important role in food fermentation. This study aims to determine the interaction between the addition of Saccharomyces cerevisiae and fermentation time on the chemical and sensory properties of the coffee produced. This research was conducted using a complete randomized block design factorial with two factors. The first factor was the coffee fermentation time (T) consisting of four levels, 12(T1), 24(T2), 36(T3) and 48(T4) hours. The second factor was the addition of Saccharomyces cerevisiae culture consisting of three levels, without the addition of culture (SO), addition of $1 \%$ S. cerevisiae culture (S1), and the addition of 3\% S. cerevisiae culture (S2). Further data analysis was done by using the Orthogonal Polynomial test. The best results in this study was the addition of $1 \%$ Saccharomycess cerevisiae and 48 hours of fermentation time producing the ground coffee with a water content of $6.43 \%$, an ash content of $4.49 \%$, a taste score of 3.17 (rather typical of coffee), a score aroma of 2.83 (somewhat typical of coffee), overall acceptance of 3.00 (somewhat typical of coffee), caffeine content of $23463.58 \mathrm{mg} / \mathrm{kg}$ and chlorogenic acid of $31769.80 \mathrm{mg}$. It can be concluded that S.cerevisiae cultured in wet coffee fermentation reduced the caffeine level of Robusta coffee and was a potential culture used for wet coffee fermentation.
\end{abstract}

Keywords: coffee fermentation, fermentation time, Robusta, Saccharomyces cerevisiae

\begin{abstract}
ABSTRAK
Kadar kafein yang tinggi pada kopi robusta dapat dikurangi dengan fermentasi kopi basah. Saccharomyces cerevisiae adalah salah satu mikroba yang dapat digunakan dalam proses fermentasi kopi. Penelitian ini bertujuan untuk mengetahui interaksi penambahan Saccharomyces cerevisiae dan waktu fermentasi terhadap sifat kimia dan sensori kopi yang dihasilkan. Penelitian ini dilakukan menggunakan metode Rancangan Acak Kelompok Lengkap (RAKL) secara faktorial dengan dua faktor. Faktor pertama adalah waktu fermentasi kopi (T) terdiri empat taraf yaitu 12(T1), 24(T2), 36(T3) dan 48(T4) jam. Faktor kedua adalah penambahan kultur Saccharomyces cerevisiae terdiri dari tiga taraf yaitu tanpa penambahan kultur (S0), penambahan kultur S. cerevisiae $1 \%(\mathrm{~S} 1$ ), dan penambahan kultur S. cerevisiae 3\% (S2). Analisis data dilanjutkan dengan menggunakan uji Ortogonal Polinomial. Hasil terbaik pada penelitian ini adalah pada perlakuan penambahan Saccharomycess cerevisiae 1\% dan waktu fermentasi $48 \mathrm{jam}$. Pada perlakuan tersebut mampu menghasilkan kopi bubuk terbaik dengan kadar air sebesar 6,43\%, kadar abu sebesar 4,49\%, skor rasa 3,17 (agak khas kopi), skor aroma 2,83 (agak khas kopi), penerimaan keseluruhan 3,00 (agak khas kopi), kadar kafein sebesar 23.463,58 mg/kg dan asam klorogenat sebesar $31.769,80 \mathrm{mg} / \mathrm{kg}$. Hal ini menunjukan bahwa fermentasi basah dengan kultur S. cerevisiae dapat mengurangi kadar kafein kopi robusta dan kultur ini berpotensial digunakan untuk kopi fermentasi basah.
\end{abstract}

Kata kunci: fermentasi kopi, Robusta, Saccharomyces cerevisiae, waktu fermentasi 


\section{PENDAHULUAN}

Kopi adalah salah satu minuman yang terkenal di dunia. Indonesia adalah salah satu negara dengan penghasil kopi yang cukup potensial. Lampung adalah salah satu penghasil kopi yang potensial di Indonesia. Lampung memiliki luas area perkebunan kopi terbesar kedua di Indonesia setelah Sumatra Selatan. Badan Pusat Statistik (2019), menunjukan luas area kopi di Lampung adalah sebesar 156.862 Ha dengan produksi kopi sebesar 110.291 ton. Hasil ini menunjukan rerata produksi kopi di Lampung yaitu sebesar $795 \mathrm{~kg} / \mathrm{Ha}$. Kopi yang banyak dihasilkan di Lampung adalah kopi jenis robusta.

Kopi robusta memiliki kadar kafein yang lebih tinggi daripada kopi arabika. Kopi robusta memiliki kadar kafein sekitar 1\%-2\% dan arabika sebesar 0,4\%-2,4\% (Farida et al, 2013). Kafein yang terdapat pada kopi adalah salah satu derivat xantin yang memiliki kemampuan sebagai stimulant syaraf otak, stimulant otot jantung, relaxasi otot polos dan meningkatkan dieresis dengan tingkatan berbeda. Menurut Bawazeer dan Alsobahi (2013), meminum minuman yang mengandung kafein akan mengalami efek samping berupa palpitasi, insomnia, nyeri kepala, tremor, gelisah, muntah dan mual.

Dekafeinasi adalah salah satu upaya untuk menurunkan kadar kafein pada biji kopi. Fermentasi kopi secara basah adalah salah satu proses yang dapat dilakukan untuk menurunkan kadar kafein. Proses fermentasi akan menurunkan kandungan kafein secara signifikan baik fermentasi hewan luwak, fermentasi basah secara penuh, maupun fermentasi dengan ragi. Kafein pada kopi akan diuraikan oleh bakteribakteri dan enzim pengurai kafein selama proses fermentasi (Hanifah dan Kurniawati, 2013). Fermentasi kopi membantu mengaktifkan enzim-enzim yang mampu menyebabkan terjadinya proses pencoklatan enzimatis sehingga biji kopi akan menghasilkan warna yang lebih coklat sehingga memperbaiki citarasa kopi. Fermentasi kopi secara basah ditandai dengan munculnya gelembung udara saat proses fermentasi walaupun suhu tidak mengalami peningkatan (Yusianto dan Nugroho, 2014).
Proses fermentasi membutuhkan starter kultur untuk menghasilkan produk yang baik. Salah satu starter kultur yang dapat diterapkan pada proses fermentasi kopi adalah Saccharomyces cerevisiae yang memiliki kemampuan fermentasi yang sering digunakan sebagai pembuatan berbagai produk makanan dan sudah banyak digunakan sebagai probiotik. S. cerevisiae memiliki kemampuan untuk menghidrolisa ikatan selulosa menjadi glukosa dan secara tidak langsung dapat menurunkan kandungan serat kasar melalui aktifitas sekunder khamir tersebut. Fermentasi kopi dipengaruhi oleh beberapa faktor yaitu jumlah inokulum bakteri, lama fermentasi, substrat (medium), suhu, oksigen, air dan tingkat keasaman $(\mathrm{pH})$. Lama inkubasi fermentasi adalah salah satu hal yang paling menentukan kualitas kopi. Sehingga, kombinasi antara penambahan Sacharomyces cerevisiae dan lama fermentasi diharapkan mampu menghasilkan kopi dengan sifat kimia dan sensori kopi menjadi lebih baik.

\section{BAHAN DAN METODE}

Bahan-bahan utama yang digunakan adalah biji kopi robusta asalan dari Liwa, kultur Saccharomyces cerevisiae, gula, garam. Peralatan yang digunakan dalam penelitian ini antara lain adalah Erlenmeyer $250 \mathrm{~mL}$, cawan petri, inkubator, hotplate, timbangan digital, $\mathrm{pH}$ meter, bunsen, gelas ukur, HPLC.

Biji kopi sebanyak $125 \mathrm{~g}$ dimasukan ke dalam erlenmeyer volume $250 \mathrm{~mL}$, ditambah air sebanyak $187,5 \mathrm{~mL}$, gula $3 \%$, garam $3 \%(\mathrm{~b} / \mathrm{b})$ serta kultur Saccharomyces cerevisiae (0\%, 1\% dan 3\%), diaduk dan ditutup dengan aluminium foil. Fermentasi dilakukan selama (12 jam, 24 jam, 36 jam dan 48 jam). Percobaan diulang sebanyak tiga kali. Pengamatan dilakukan pada biji kopi hasil fermentasi ( $\mathrm{pH}$ dan total mikroba) dan kopi bubuk (sifat sensori). Data yang diperoleh diuji kesamaan ragamnya dengan menggunakan uji Bartlet. Data dianalisis dengan sidik ragam untuk mengetahui pengaruh antar perlakuan. Analisis data dilanjutkan dengan menggunakan uji Ortogonal Polinomial. 


\subsection{Kadar Air}

Kopi bubuk diujikan dengan metode gravimetri AOAC (2005). Sampel kopi bubuk sebanyak $5 \mathrm{~g}$ dimasukan ke dalam cawan. Cawan porselen dioven dan ditimbang terlebih dahulu sebelum digunakan selama 30 menit. Kemudian, cawan berisi kopi bubuk dimasukkan ke oven dengan suhu $100-105^{\circ} \mathrm{C}$ selama 3 jam lalu dimasukan dalam desikator dan ditimbang, diulang hingga berat konstan. Kadar air $(K A)$ dihitung dengan Persamaan 1.

$$
K A=\frac{c-(a-b)}{c} * 100 \%
$$

dimana $a$ adalah berat cawan dan sampel akhir (g), $b$ adalah berat cawan (g), dan $c$ adalah berat sampel awal (g).

\subsection{Kadar Abu}

Kadar abu kopi bubuk diuji dengan metode gravimetri (AOAC, 2005). Sampel sebanyak $5 \mathrm{~g}$ diletakkan di dalam cawan porselen. Cawan poselen dikeringkan didalam oven dengan suhu 100-105 ${ }^{\circ} \mathrm{C}$, kemudian didinginkan dalam desikator dan ditimbang. Kemudian cawan perselen yang berisi sampel dipijarkan diatas kompor listrik sampai tidak berasap lagi. Kemudian cawan porselen dipijarkan di furnace dengan suhu $550-600^{\circ} \mathrm{C}$ selama 4-6 jam atau sampai abu berwarna putih. Sampel kemudian didinginkan didalam desikator dan ditimbang. Perhitungan kadar abu adalah sebagai berikut:

$$
K_{a b u}=\frac{B A}{B S} * 100 \%
$$

dimana, $K_{\text {abu }}$ adalah kadar abu, $B A$ adalah berat abu (g), dan $B S$ adalah berat sampel kering (g).

\subsection{Kadar Kafein}

Analisis kadar kafein (Fajara dan Susanti, 2017) dilakukan dengan menimbang $5 \mathrm{~g}$ sampel halus (30 mesh) ke dalam erlenmeyer, kemudian dimasukkan $5 \mathrm{~g}$ MgO ditambah $200 \mathrm{ml}$ aquabides. Kemudian erlenmeyer dipanaskan selama 20 menit suhu mendidih sambil diaduk-aduk. Setelah itu, larutan itu didinginkan dalam suhu ruang. Larutan kemudian disaring dengan catridge filter $0,2 \mu \mathrm{m}$ dan diinjeksi ke dalam HPLC.

$$
K K=\frac{D U * V i s *(\text { Vas*200) }}{(\text { Vistd } * 50)}
$$

dimana $K K$ adalah kadar kafein, $D U$ adalah deret ukur, Vistd adalah volume injeksi standar, Vas adalah volume akhir sampel, Vis adalah volume injeksi sampel, dan $S$ adalah massa contoh (g). Faktor konversi $\mathrm{N}$ ke kafein $=3,464$

\subsection{Analisis Asam Klorogenat}

Sampel bubuk kopi disiapkan seberat $2 \mathrm{~g}$ dan ditambahkan $75 \mathrm{~mL}$ metanol adan $75 \mathrm{~mL}$ aquabides. Kemudian larutan dipanaskan selama 1 jam suhu mendidih dan didinginkan dalam suhu ruang. Kemudian sampel disaring dengan catridge filter $0,2 \mu \mathrm{m}$ dan diinjeksikan pada HPLC (Craig et al, 2016).

$$
H A=\frac{K d s * V i s t d * \frac{V a s}{V i s}}{B S}
$$

dimana $H A$ adalah hasil analisa, $K d s$ adalah konsentrasi berdasarkan deret standard.

\section{HASIL DAN PEMBAHASAN}

\section{1. pH}

pH bji kopi sebelum dilakukan fermentasi pada penelitan ini berkisar antara 6,32-7,94. Hasil analisis ragam memperlihatkan bahwa penambahan Saccharomyces cerevisae, waktu fermentasi dan interaksi keduanya tidak berpengaruh nyata terhadap pH biji kopi yang dihasilkan. pH biji kopi setelah dilakukan fermentasi pada penelitian ini berkisar antara 4,16-7,16. Hasil analisis ragam memperlihatkan bahwa penambahan Saccharomyces cerevisae, waktu fermentasi dan interaksi keduanya sangat berpengaruh nyata terhadap $\mathrm{pH}$ biji kopi yang dihasilkan. Hasil uji lanjut polinomial ortogonal menunjukan penambahan Saccharomyces cerevisiae dan waktu fermentasi berpengaruh nyata terhadap kadar $\mathrm{pH}$ yang dihasilkan namun interaksi keduanya tidak berpengaruh nyata.

Semakin lama waktu fermentasi, maka pH biji kopi yang dihasilkan cenderung semakin menurun secara linier. Proses fermentasi yang semakin lama akan menghasilkan asam-asam organik yang semakin banyak pada biji kopi yang difermentasi. Menurut Kurniawan dan Hastuti (2014), semakin banyak khamir maka semakin tinggi enzim amilase, zymase dan invertase semakin meningkat. Afifah (2010) menyatakan 
bahwa selama proses fermentasi, khamir akan merombak gula menjadi etanol dan akan dirobak oleh bakteri asetat menjadi asam-asam organik.

Semakin tinggi persentase inokulum Saccharomycess cerevisiae yang digunakan (Gambar 1), maka pH biji kopi yang dihasilkan semakin menurun secara linier. Semakin tinggi persentase inokulum, maka semakin banyak Saccharomycess cerevisiae yang bekerja untuk mensintesis gula menjadi asam-asam yang mampu menurunkan $\mathrm{pH}$. Menurut Hadipernata dan Nugraha (2012) proses pemecahan gula akan menghasilkan asam laktat dan asam-asam lain yaitu etanol, asam butirat, dan propionate. Asam-asam yang terbentuk ini akan menyebabkan $\mathrm{pH}$ menjadi asam.

\subsection{Kadar Air}

Kadar air kopi bubuk pada penelitian ini berkisar antara 5,26-7,60\%. Hasil analisis ragam memperlihatkan bahwa penambahan Saccharomycess cerevisiae sangat berpengaruh nyata terhadap kadar air kopi bubuk sedangkan waktu fermentasi berpengaruh nyata. Interaksi antara penambahan Saccharomycess cerevisiae dan waktu fermentasi tidak berpengaruh sangat nyata. Hasil uji lanjut polinomial ortogonal menunjukan penambahan Saccharomycess cerevisiae berpengaruh sangat nyata terhadap kadar air kopi bubuk.

Semakin tinggi persentase inokulum Saccharomyces cerevisiae yang digunakan (Gambar 2), maka kadar air kopi bubuk yang

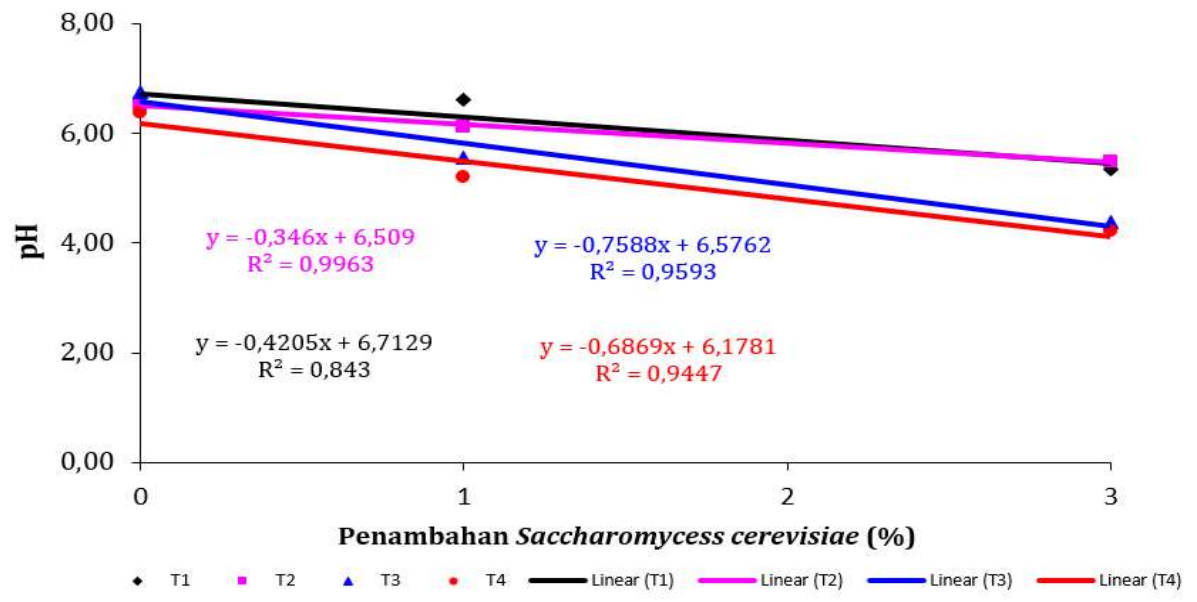

Gambar 1. Pengaruh Penambahan Saccharomycess cerevisiae Terhadap pH Biji Kopi Terfermentasi (Keterangan Waktu Fermentasi: $\mathrm{T} 1=12 \mathrm{jam}, \mathrm{T} 2=24 \mathrm{jam}, \mathrm{T} 3=36 \mathrm{jam}, \mathrm{T} 4=48$ jam)

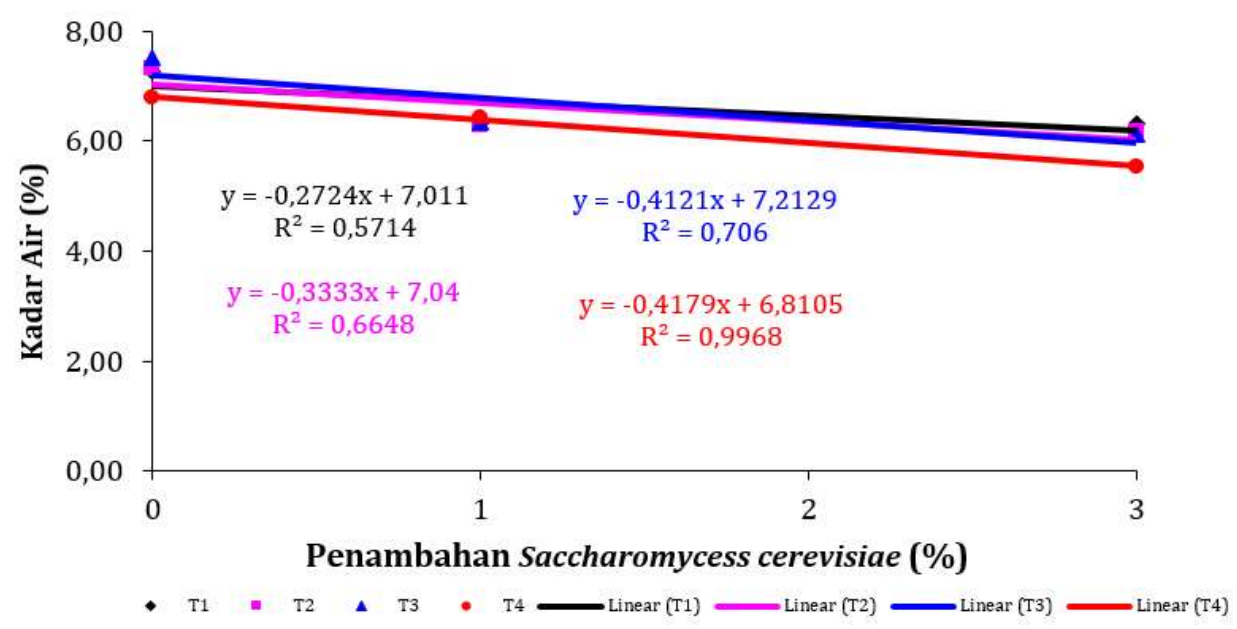

Gambar 2. Pengaruh Penambahan Saccharomyces cerevisiae Terhadap Kadar Air Kopi Bubuk (Keterangan pada Gambar 1 Berlaku) 
dihasilkan menurun secara linier. Persentase inokulum yang tinggi menyebabkan aktivitas mikroba semakin tinggi yang menyebabkan terjadinya kenaikan suhu. Kenaikan suhu ini akan mengubah lendir dari biji kopi menjadi encer dan pori-pori biji kopi terbuka dan terjadi proses penguapan. Proses fermentasi ini juga akan mengubah lendir menjadi alkohol dari senyawa-senyawa gula yang bersifat higroskopis di dalam lendir (Murthy dan Naidu, 2011). Hal ini mengakibatkan biji kopi yang dikeringkan dan diolah menjadi kopi bubuk akan mengalami penurunan kadar air dengan jumlah inokulum yang semakin banyak.

Proses fermentasi kopi oleh Saccharomyces cerevisiae akan mengakibatkan kopi menyerap banyak air, sehingga meningkatkan bobot biji kopi yang terfermentasi. Aktivitas mikroba dalam fermentasi ini akan merombak makromolekul seperti pati, lemak, protein menjadi senyawa yang lebih sederhana sehingga air mampu berdifusi ke dalam sel yang terdapat pada biji kopi (Mahendra et al., 2019). Namun, kopi akan kembali melakukan penyusutan saat proses pengeringan. Kopi akan menyusut juga saat proses penyangraian.

\subsection{Kadar Abu}

Kadar abu kopi bubuk pada penelitian ini berkisar antara 3,609\%-5,033\%. Hasil analisis ragam memperlihatkan bahwa penambahan Saccharomyces cerevisiae tidak berpengaruh nyata terhadap kadar abu kopi bubuk sedangkan waktu fermentasi sangat berpengaruh nyata. Interaksi antara penambahan Saccharomyces cerevisiae dan waktu fermentasi berpengaruh nyata terhadap kadar abu kopi bubuk. Hasil uji lanjut polinomial ortogonal menunjukan waktu fermentasi sangat berpengaruh nyata terhadap kadar abu kopi bubuk.

Semakin banyak Saccharomyces cerevisiae pada biji kopi (Gambar 3), maka kadar abu kopi bubuk yang dihasilkan meningkat secara linier. Semakin lama proses fermentasi maka kadar abu akan meningkat (Barus, 2019). Semakin lama fermentasi pada biji kopi maka selama proses fermentasi terjadi perombakan komponenkomponen zat di dalam biji kopi akibat selama proses fermentasi menghasilkan panas. Kopi sendiri memiliki beberapa kandungan mineral yaitu potassium, kalium, kalsium, magnesium dan mineral non-logam yaitu fosfor dan sulfur (Barus, 2019).

\subsection{Total Mikroba}

Hasil analisis ragam memperlihatkan bahwa penambahan Saccharomyces cerevisiae berpengaruh nyata terhadap total mikroba biji kopi sedangkan waktu fermentasi sangat berpengaruh nyata. Interaksi antara penambahan Saccharomyces cerevisiae dan waktu fermentasi tidak berpengaruh sangat nyata. Hasil uji lanjut polinomial ortogonal menunjukan waktu fermentasi berpengaruh nyata terhadap total mikroba biji kopi.

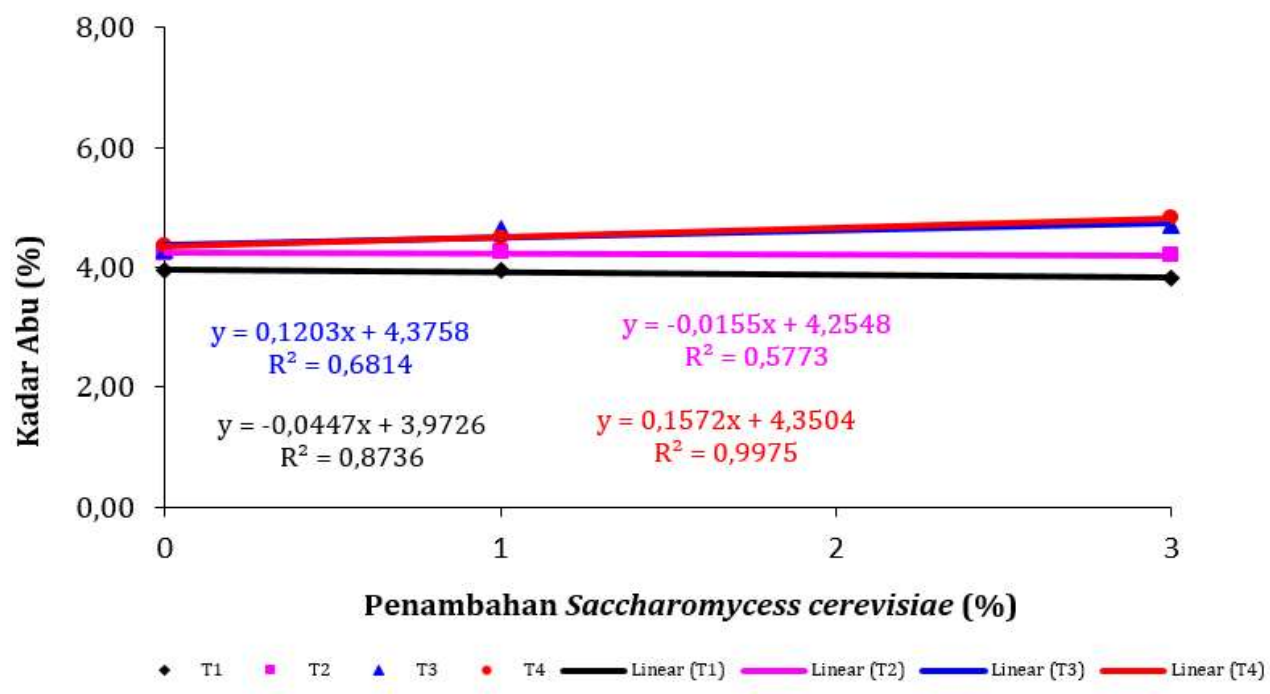

Gambar 3. Pengaruh Waktu Fermentasi Terhadap Kadar Abu Biji Kopi Terfermentasi (Keterangan pada Gambar 1 Berlaku) 
Semakin lama waku fermentasi, total mikroba yang dihasilkan pada biji kopi akan meningkat secara linier (Gambar 4). Pertumbuhan total mikroba ini karena adanya peningkayan mikroba yang semakin lama semakin meningkat yang ditandai dengan munculnya gelembunggelembung saat proses fermentasi biji kopi. Selama terjadi proses fermentasi biji kopi, terdapat aktivitas mikroorganisme terutama khamir yang merombak lapisan lendir menjadi senyawa asam-asam organik (Yusianto dan Widyotomo, 2013).

\subsection{Aroma}

Hasil analisis ragam pada lampiran memperlihatkan bahwa penambahan Saccharomyces cerevisiae dan waktu fermentasi sangat berpengaruh nyata terhadap aroma kopi bubuk yang sudah diseduh. Interaksi antara penambahan Saccharomyces cerevisiae dan waktu fermentasi sangat berpengaruh nyata terhadap aroma kopi bubuk yang sudah diseduh. Hasil uji lanjut polinomial ortogonal menunjukan penambahan Saccharomyces cerevisiae, waktu fermentasi dan interaksi keduanya sangat berpengaruh nyata terhadap aroma kopi bubuk yang sudah diseduh.

Semakin lama waktu fermentasi maka nilai rerata aroma semakin meningkat secara linier (Gambar 5) dan semakin tinggi konsentrasi Saccharomyces cerevisiae tidak menunjukan peningkatan nilai rerata yang signifikan. Pengujian aroma dilakukan pada kopi bubuk yang sudah diseduh. Nilai rerata aroma yang semakin tinggi dapat terjadi karena proses fermentasi akan membentuk senyawa volatile yang terbentuk akibat adanya reaksi gula reduksi, asam organik, lipid dan asam amino yang mampu menguraikan karbohidrat dan protein yang berlangsung selama proses fermentasi (Saputra et al, 2019).

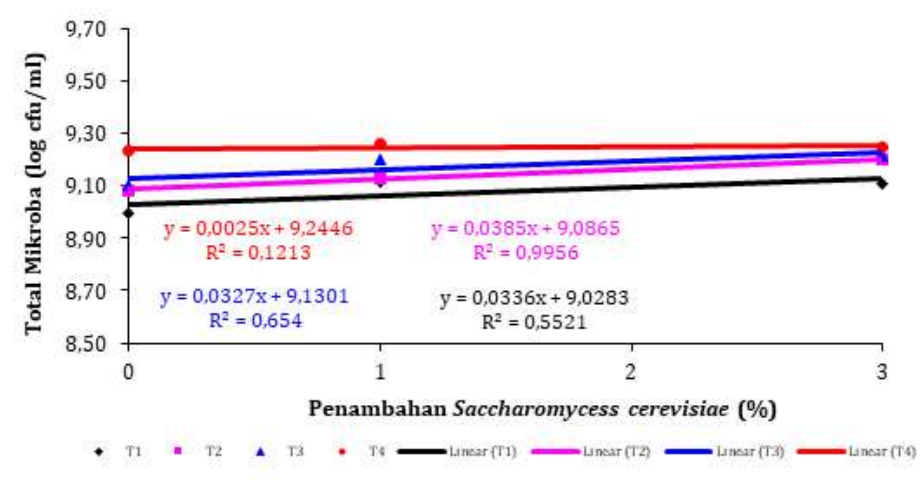

Gambar 4. Pengaruh Penambahan Saccharomyces cerevisiae Terhadap Total Mikroba Biji Kopi Terfermentasi (Keterangan pada Gambar 1 Berlaku)

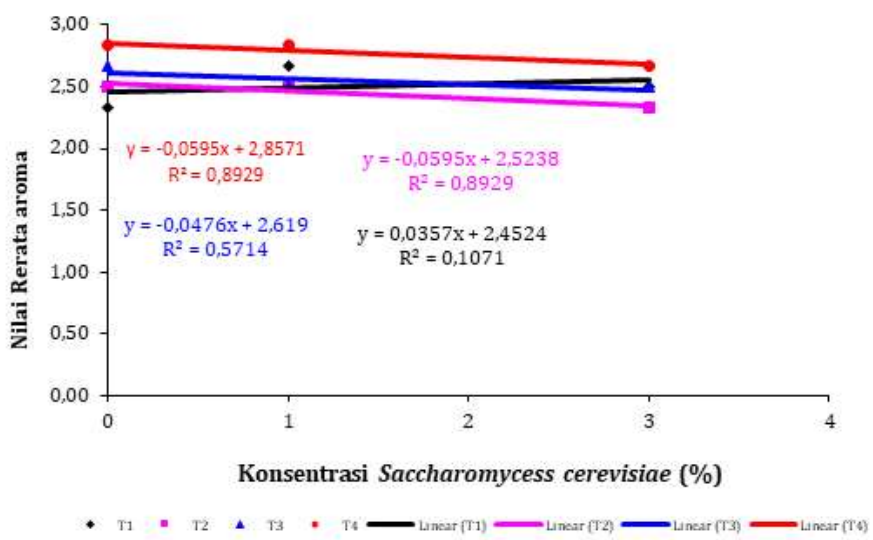

Gambar 5. Pengaruh Penambahan Saccharomyces cerevisiae Terhadap Nilai Rerata Aroma Kopi Bubuk Terfermentasi (Keterangan pada Gambar 1 Berlaku. Nilai Rata-rata Aroma: 1 = Tidak Khas Kopi; 2 = Kurang Khas Kopi; 3 = Netral; 4 = Khas Kopi; 5 = Sangat Khas Kopi) 


\subsection{Rasa}

Hasil analisis ragam pada lampiran memperlihatkan bahwa penambahan Saccharomyces cerevisiae tidak berpengaruh nyata terhadap aroma kopi bubuk yang sudah diseduh namun waktu fermentasi sangat mempengaruhi. Interaksi antara penambahan Saccharomyces cerevisiae dan waktu fermentasi tidak berpengaruh nyata terhadap rasa kopi bubuk yang sudah diseduh. Hasil uji lanjut polinomial ortogonal menunjukan waktu fermentasi sangat berpengaruh nyata terhadap rasa kopi bubuk yang sudah diseduh.

Semakin banyak penambahan Saccharomyces cerevisiae, maka nilai rerata rasa meningkat secara linier namun peningkatan tidak terlalu tinggi (Gambar 6). Proses fermentasi yang semakin lama akan membentuk senyawa prekusor citarasa seperti asam organik, asam amio dan gula reduksi (Lin, 2010). Proses fermentasi yang semakin lama akan mendegradasi protein pada kopi menjadi oligopeptida, dipeptide dan selanjutnya menjadi asam-asam amino. Menurut Janzen (2010), kandungan protein yang semakin rendah pada kopi maka rasa yang ditimbulkan pada kopi semakin tidak pahit. Perombakan protein ini akan menyebabkan rasa gurih pada kopi. Rasa gurih ini adalah rasa yang diinginkan dalam proses fermentasi sehingga diharapkan menghasilkan rasa balance.

\subsection{Penerimaan Keseluruhan}

Hasil analisis ragam pada lampiran memperlihatkan bahwa penambahan

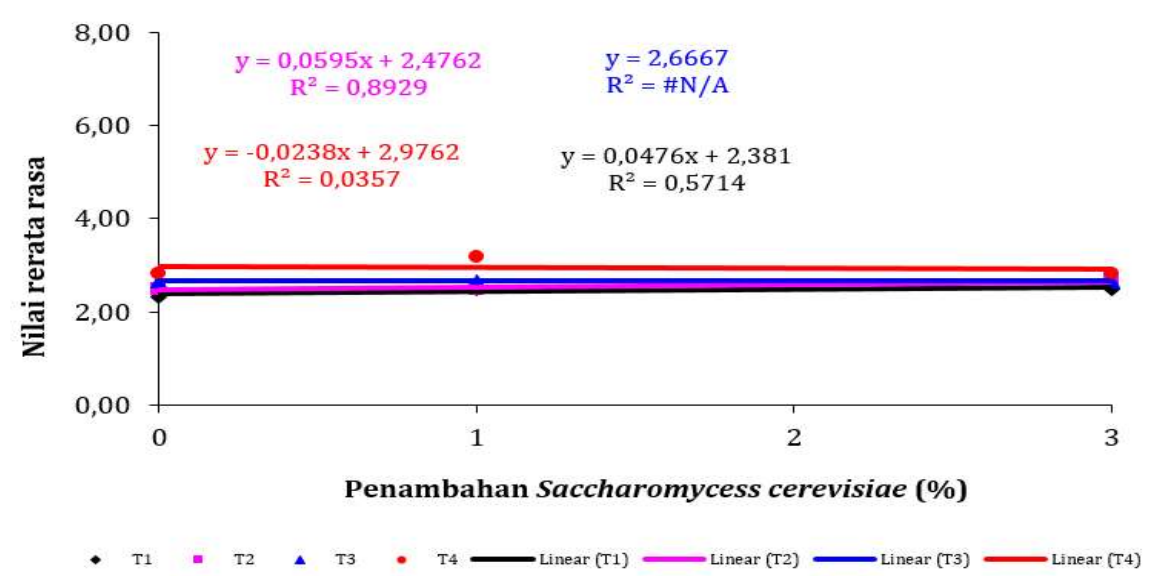

Gambar 6. Pengaruh Penambahan Saccharomyces cerevisiae Terhadap Nilai Rerata Rasa Kopi Bubuk Terfermentasi (Keterangan pada Gambar 1 Berlaku. Nilai Rata-rata Rasa: 1 = Tidak Khas

Kopi; 2 = Kurang Khas Kopi; 3 = Netral; 4 = Khas Kopi; 5 = Sangat Khas Kopi)

Saccharomyces cerevisiae berpengaruh nyata terhadap penerimaan keseluruhan kopi bubuk yang sudah diseduh dan waktu fermentasi sangat mempengaruhi. Interaksi antara penambahan Saccharomyces cerevisiae dan waktu fermentasi tidak berpengaruh nyata terhadap penerimaan keseluruhan kopi bubuk yang sudah diseduh. Hasil uji lanjut polinomial ortogonal menunjukan waktu fermentasi berpengaruh nyata terhadap penerimaan keseluruhan kopi bubuk yang sudah diseduh.

Semakin tinggi penambahan Saccharomyces cerevisiae maka nilai rerata penerimaan keseluruhan meningkat secara linier. Hal ini sangat di pengaruhi oleh rasa dan aroma pada kopi. Penerimaan keseluruhan ini sebanding dengan nilai rerata aroma dimana penambahan Saccharomyces cerevisiae $1 \%$ memiliki peningkatan lebih tinggi dibandingkan konsentrasi lainnya. Penerimaan keseluruhan juga berbanding dengan nilai rerata rasa dimana terjadi peningkatan secara linier namun tidak signifikan. Penilaian lainnya pada skor penerimaan keseluruhan mungkin juga dipengaruhi aftertaste setelah mencoba kopi bubuk yang sudah diseduh. Kesukaan kopi juga dipengaruhi oleh banyak hal dimana pada panelis terlatih menilai kopi dengan berbagai parameter yaitu aroma (bau aroma saat diseduh), flavour (rasa dilidah), body (kekentalan), acidity (keasaman), aftertaste (rasa yang tertinggal dimulut), sweetness (rasa manis), balance (aspek keseimbangan rasa), clean cup (kesan rasa umum), uniformity (adanya keseragaman rasa dari tiap cangkir), dan

$\mathrm{y}=2,6667$

$0,0476 x+2,38$ $\mathrm{R}^{2}=0,571$ 


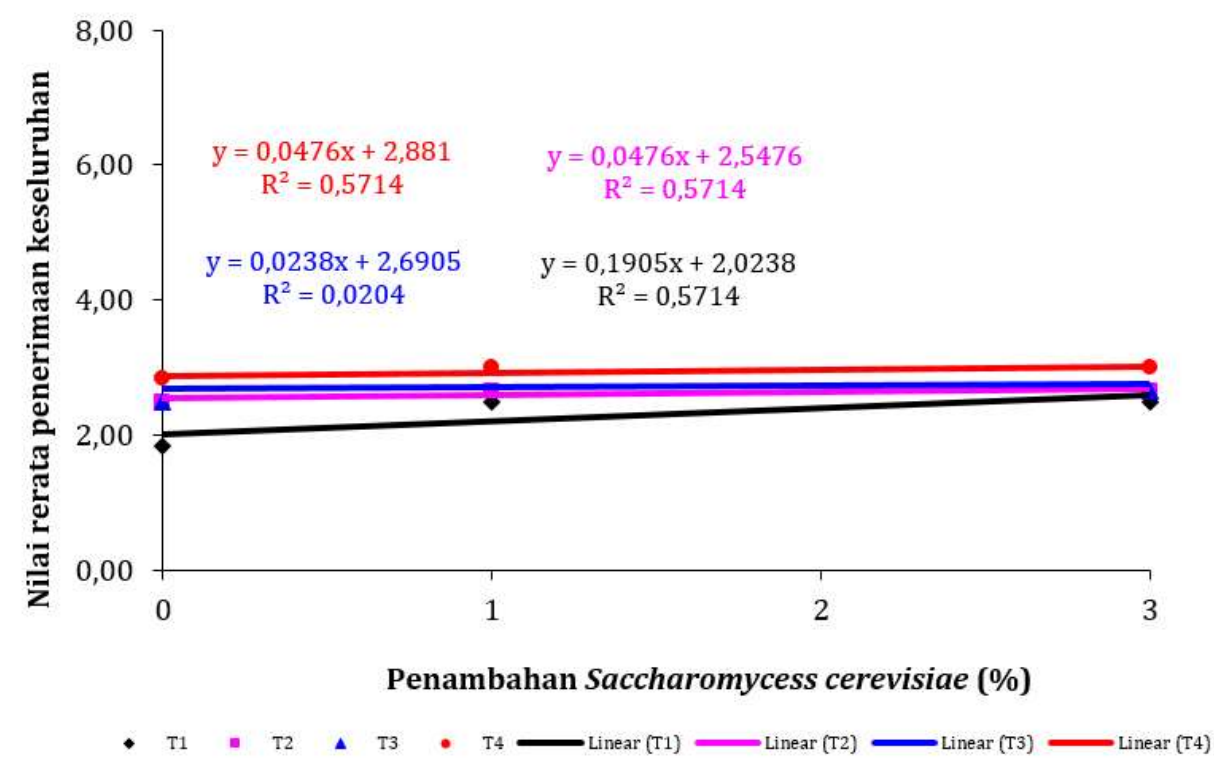

Gambar 7. Pengaruh Penambahan Saccharomyces cerevisiae Terhadap Nilai Rerata Penerimaan

Keseluruhan Kopi Bubuk Terfermentasi (Keterangan pada Gambar 1 Berlaku. Nilai Rata-rata Penerimaan Keseluruhan: 1 = Tidak Suka; 2 = Kurang Suka; $3=$ Netral; $4=$ Suka; $5=$ Sangat Suka)

Tabel 1. Rekapitulasi Hasil Pengamatan Uji Kadar Air, Kadar Abu, Aroma, Rasa dan Penerimaan Keseluruhan

\begin{tabular}{|c|c|c|c|c|c|c|c|c|c|c|c|c|c|}
\hline \multirow{2}{*}{ Parameter } & \multicolumn{12}{|c|}{ Perlakuan } & \multirow{2}{*}{$\begin{array}{c}\text { Standar } \\
\text { SNI 01- } \\
3542- \\
2004 \\
\end{array}$} \\
\hline & S0T1 & S0T2 & S0T3 & S0T4 & S1T1 & S1T2 & S1T3 & S1T4 & S2T1 & S2T2 & S2T3 & S2T4 & \\
\hline kadar air & 7.28 & 7.31 & 7.52 & $6.78^{*}$ & $6.33^{*}$ & $6.30^{*}$ & $6.34^{*}$ & $6.43^{*}$ & $6.33^{*}$ & $6.18^{*}$ & $6.13^{*}$ & $5.54^{*}$ & maks 7\% \\
\hline kadar abu & $3.95^{*}$ & $4.24^{*}$ & $4.28^{*}$ & $4.36^{*}$ & $3.96^{*}$ & $4.26^{*}$ & $4.64^{*}$ & $4.49 *$ & 3.83* & $4.20^{*}$ & $4.69^{*}$ & $4.83^{*}$ & maks $5 \%$ \\
\hline aroma & 2.33 & 2.50 & 2.67 & $2.83^{*}$ & 2.67 & 2.50 & 2.50 & $2.83^{*}$ & 2.50 & 2.33 & 2.50 & 2.67 & \\
\hline rasa & 2.33 & 2.50 & 2.67 & 2.83 & 2.50 & 2.50 & 2.67 & $3.17^{*}$ & 2.50 & 2.67 & 2.67 & 2.83 & \\
\hline $\begin{array}{l}\text { Penerimaan } \\
\text { keseluruhan } \\
\end{array}$ & 1.83 & 2.50 & 2.50 & 2.83 & 2.50 & 2.67 & $3.00^{*}$ & $3.00^{*}$ & 2.50 & 2.67 & 2.67 & $3.00^{*}$ & \\
\hline$\Sigma$ & 1 & 1 & 1 & 3 & 2 & 2 & 3 & 5 & 2 & 2 & 2 & 3 & \\
\hline
\end{tabular}

\subsection{Perlakuan Terbaik}

Penentuan perlakuan terbaik untuk kopi bubuk dengan perlakuan penambahan konsentrasi Saccharomyces cerevisiae dan waktu fermentasi dilakukan dengan mempertimbangkan berbagai parameter yang dianalisis pada perlakuan yang diberikan diantaranya yaitu kadar air, kadar abu, rasa, aroma, dan penerimaan keseluruhan. Berikut rekapitulasi hasil pengamatan pada kopi bubuk (Tabel 1).

Penentuan perlakuan terbaik ditentukan berdasarkan jumlah bintang perlakuan kadar air dan kadar abu yang sesuai dengan SNI 01-3542-
2004 (BSN, 2004). Berdasarkan hasil rekapitulasi, seluruh perlakuan kecuali S0T1, S0T2 dan S0T3 memenuhi perlakuan kadar air dimana kurang dari 7\% (b/b). Hasil kadar abu secara keseluruhan memiliki kadar abu yang sesuai dengan SNI 01-3542-2004 yaitu kurang dari 5\% (b/b). Hasil yang sesuai dengan SNI diberi tanda bintang untuk melihat hasil terbaik. Berdasarkan jumlah bintang maka S0T1, S0T2 dan S0T3 memiliki jumlah bintang satu dan sisanya memiliki jumlah bintang dua. Hasil terbaik blmbisa ditentukan sehingga hasil terbaik dilihat dengan menggunakan hasil uji sensori. 
Tabel 2. Hasil Uji Kafein dan Asam Klorogenat Kopi Bubuk

\begin{tabular}{ccc}
\hline Perlakuan & Kafein $(\mathbf{m g} / \mathbf{k g})$ & Asam Klorogenat $\mathbf{~ m g / k g )}$ \\
\hline S1T2 & $26.773,52$ & $31.769,80$ \\
S1T4 & $23.463,58$ & $44.530,81$ \\
\hline
\end{tabular}

Pengujian sensori berperan penting dalam penerimaan produk di masyarakat karena panelis dapat mengidentifikasi sifat-sifat sensori yang akan membantu untuk mendeskripsikan produk. Panelis yang digunakan pada penelitian ini adalah panelis yang bekerja di salah satu tempat kopi di Bandar Lampung sehingga sudah terbiasa merasakan kopi. Berdasarkan parameter pada uji sensori yang telah dilakukan, perlakuan S0T4 dan S1T4 memiliki nilai rerata aroma tertinggi dengan skor 2,83. Perlakuan S1T4 memiliki nilai rerata rasa tertinggi dengan skor 3,17. Perlakuan S1T3, S1T4 dan S2T4 memiliki nilai rerata penerimaan keseluruhan tertinggi dengan skor 3,00. Setiap perlakuan yang memiliki nilai tertinggi diberikan bintang dan direkapitulasi total bintang. Hasil rekapitulasi menunjukan kopi bubuk dengan perlakuan S1T4 memiliki jumlah terbaik dan menjadi perlakuan terbaik.

\subsection{Uji Kafein dan Asam Klorogenat}

Berdasarkan hasil penentuan perlakuan terbaik, maka dipilih kopi dengan perlakuan S1T4 (penambahan Saccharomycess cerevisiae 1\% dengan waktu fermentasi 48 jam) yang kemudian diujikan kadar kafein dan asam klorogenat. Pengujian dilakukan pada 2 sampel S1T2 dan S1T4 (Tabel 2) untuk melihat pengaruh waktu fermentasi pada kopi bubuk. Hasil pengujian menunjukan perlakuan kontrol memiliki kadar kafein dan asam klorogenat terendah.

Hasil kadar kafein menunjukan bahwa kontrol memiliki nilai kafein yang lebih tinggi dibandingan penambahan Saccharomyces cerevisiae sebanyak $1 \%$. Perlakuan penambahan Saccharomyces cerevisiae sebanyak 1\% menunjukan semakin lama waktu fermentasi maka kadar kafein mengalami penurunan. Hasil perlakuan yang difermentasi dengan Sacharomyces cerevisiae 1\% selama 24 jam memiliki nilai kafein yang lebih tinggi dibandingkan kopi bubuk yang difermentasi selama 48 jam. Kadar kafein mengalami penurunan dari fermentasi 24 jam ke 48 jam karena pengaruh waktu fermentasi.

Semakin lama waktu fermentasi, hasil asam klorogenat mengalami peningkatan. Asam klorogenat dengan waktu fermentasi 48 jam memiliki nilai yang lebih tinggi dibandingkan 24 jam. Penambahan Sacharomyces cerevisiae juga mampu meningkatkan asam klorogenat dimana hasil asam klorogenat dengan penambahan Sacharomyces cerevisiae 1\% memiliki asam klorogenat yang lebih tinggi dibandingkan dengan kontrol. Proses fermentasi menyebabkan kandungan kafein diubah menjadi senyawa ester berupa asam klorogenat melalui proses esterifikasi. Proses esterifikasi ini yang mengubah senyawa kompleks kafein menjadi asam klorogenat (Tawali et al, 2013). Hal lain yang menyebabkan terjadi peningkatan asam klorogenat adalah karena pengujian ini dilakukan dengan kadar berat basah. Etanol pada proses fermentasi akan bereaksi dengan asam klorogenat sehingga menghasilkan ester-ester asam klorogenat. Ester-ester ini yang mungkin terhitung sebagai asam klorogenat.

\section{KESIMPULAN DAN SARAN}

\subsection{Kesimpulan}

Penambahan Saccharomycess cerevisiae 1\% menghasilkan kopi bubuk terbaik. Waktu fermentasi 48 jam menghasilkan kopi bubuk terbaik. Penambahan Saccharomycess cerevisiae 1\% dan waktu fermentasi 48 jam menghasilkan kopi bubuk terbaik dengan kadar air sebesar 6,43\%, kadar abu sebesar 4,49\%, skor rasa 3,17 (Agak khas kopi) , skor aroma 2,83 (agak khas kopi) , penerimaan keseluruhan 3,00 (agak khas kopi) , kadar kafein sebesar $23463,58 \mathrm{mg} / \mathrm{kg}$ dan asam klorogenat sebesar $31769,80 \mathrm{mg}$.

\subsection{Saran}

Perlu dilakukan penelitian lanjutan dengan penambahan waktu 0 jam dan penambahan 
konsentrasi 2\% untuk pengujian kopi bubuk terfermentasi dan perlu dilakukan penelitian lanjutan dengan membandingkan berbagai jenis inokulum yang berbeda.

\section{DAFTAR PUSTAKA}

Afifah, N. 2010. Analisis Kondisi dan Potensi Lama Fermentasi Medium Kombucha (Teh, Kopi, Rosela) dalam Menghambat Pertumbuhan Bakteri Patogen (Vibrio Cholerae dan Bacillus Cereus). Skripsi. UIN Malang, Malang.

AOAC. 2005. Official Methods of Analysis of The Association of Official Analytical Chemist. AOAC Inc., Washington.

BPS (Badan Pusat Statistik). 2019. Statistik Kopi Indonesia 2019. ISSN: 2714-8505.

BSN (Badan Standardisasi Nasional). 2004. SNI 01-3542-2004. Kopi Bubuk. Jakarta.

Barus, W.B.J. 2019. Pengaruh lama fermentasi dan lama pengeringan terhadap mutu bubuk kopi. Wahana Inovasi, 8(2): 111-115.

Craig, A.P., Fields, C., Liang, N., Kitts, D. dan Erickson, A. 2016. Performance review of a fast HPLCUV method for the quantification ofchlorogenic acids in green coffee bean extracts. Talanta, 154: 481-485.

Fajara, B.E.P, dan Susanti, H. 2017. HPLC determination of caffeine in coffee beverage. IOP Conf. Ser.: Mater. Sci. Eng. 259: 012011.

Hadipernata, M., R. Thahjohutomo, I. Agustinisari dan E. Rahayu. 2011. Teknologi Proses dan Keamanan Pangan Kopi.
Janzen, O.S. 2010. Chemistry of coffee. In M. Lew and L. Hung-Wen (Eds.), Comprehensive Natural Products II. Oxford, Elsevier : 1085-1117.

Kurniawan, W.M. dan Hastuti, K. 2017. Penentuan kualitas biji kopi arabika dengan menggunakan Analytical Hierarchy Process (Studi kasus pada Perkebunan Kopi Lereng Gunung Kelir Jambu Semarang). J. SIMETRIS. 8(2): 519-528.

Lin, C.C. 2010. Approach of improving coffee industry in Taiwan promote quality of coffee bean by fermentation. The Journal of International Management Studies, 5(1): 154-159.

Murthy, P.S. dan Naidu, M.M. 2011. Improvement of robusta coffee fermentation with microbial enzymes. European Journal of Applied Sciences, 3(4): 130-138.

Saputra, A.P.A., Baco, A.R., dan Asyik, N. 2019. Fermentasi ragi tape (Saccharomycess cerevisiae) terhadap sifat fisik, kimia dan organoleptik produk kopi bubuk robusta (Coffea coraphora). J. Sains dan Teknologi Pangan, 4(6): 2555-2566.

Setyohadi. 2006. Proses Mikrobiologi Pangan (Proses Kerusakan dan

Tawali, A.B., Abdullah, N., dan Wiranata, B.S. 2013. Pengaruh fermentasi menggunakan bakteri asam laktat yoghurt terhadap citarasa kopi robusta (coffea robusta). Universitas Hasanudin, Makassar: 90-97.

Yusianto dan Widyotomo, S. 2013.Optimasi proses fermentasi biji kopi arabika dalam fermentor terkendali. Pelita Perkebunan, 29: 53-68. 